\title{
ĐẶC ĐIỂM BIẾN ĐộNG TRÀ̀M TÍCH LƠ LỬNG TRONG MÙA LŨ NĂM 2013 TẠI VÙNG CƯA SÔNG VEN BỜ ĐỒNG BẰNG SÔNG CỦU LONG
}

\author{
Nguyễn Bá Thủy ${ }^{1}$ Vũ Hải Đăng
}

Tóm tắt: Đặc điểm biến động theo không gian và thời gian của trầm tích lơ lủng trong mùa lũ năm 2013 tại vùng cưa sông ven bò̀ đồng bằng sông Cưu Long đã được làm sáng tỏ dựa trên việc phân tích số liệu độ đục và độ muối của 65 trạm đo mặt rộng trong tháng 9/2013. Số liệu độ đục và độ muối tù̀ mặt đến đáy được đo bằng thiết bị AAQ1183s-IF. Anh hương của triều đối với các đặc trung động lục trầm tích lở lửng được phân tích dựa trên số liệu triều dụ báo tại khu vực nghiên cứu. Các kết quả phân tích số liệu cho thấy phân bố không gian và thời gian của độ đục tại vùng cửa sông Cửu Long trong mùa lũ chịu ảnh hưởng của hai chế độ động lục chính: chế độ thủy văn tại các cửa sông và chế độ triều. Theo không gian, phân bố độ đục có xu huớng giảm dần tù̀ vùng cửa sông ra vùng ngoài khơi do ảnh hưởng của nguồn trầm tích sông cùng với hoạt động mạnh của thủy triều. Tại vùng cửa sông, độ đục có thể lên tới hơn 800 NTU (Nephelometric Turbidity Units). Phân bố thẳng đứng của độ đục biến đổi phụ thuộc vào vị trí quan trắc và thời điểm quan trắc theo pha triều. Ở một số trạm quan trắc được sụ tăng đột biến của độ đục tại lớp sát đáy có thể lên 140 NTU, mặc dù độ muối khá cao và thời điểm đo nằm trong pha triều lên. Hiện tuợng này có thể liên quan tới quá trình tái lo lưng của trầm tích do dòng triều trong pha triều lên. Nhìn chung, các trạm tại khu vục cưa sông Hậu có độ đục cao hơn so với các trạm tại khu vục cưa sông Tiền.

Từ khóa: Động lục trầm tích lo lưng, độ đục, độ muối, thủy triều, cửa sông Cửu Long.

Ban Biên tập nhận bài: 16/2/2019 Ngày phản biện xong: 25/04/2019 Ngày đăng bài: 25/05/2019

\section{Mở đầu}

Vùng tiếp giáp giữa biển-đất liền tạo thành một trong những con đường vận chuyển nước và các vật liệu của chu trình sinh-địa-hóa và thủy văn toàn cầu. Trong đó, các dòng sông bổ sung trầm tích cho sự mất đi bởi các quá trính xói lở dọc theo vùng ven bờ, cũng như xói lở ngang bờ ra khơi và các thành phần sinh học thiết yếu để nuôi dưỡng các hệ sinh thái ven bờ. Một trong những quá trình cuối cùng của sự vận chuyển vật liệu trầm tích xuất hiện thông qua sự phân tỏa các vật chất lơ lửng từ cửa sông vào vùng thềm lục địa. Do có nồng độ trầm tích lơ lửng cao, những vùng nước này có thể phân biệt rõ ràng với phần nước biển trong thông qua độ đục. Biến

${ }^{1}$ Trung tâm Dư báo Khi tượng Thủy văn Quốc Gia 2Viện Địa chất và Địa vật lý biển. VAST

Email: thuybanguyen@gmail.com động của lưu lượng nước sông, lưu lượng trầm tích sông, chế độ triều, chế độ sóng gió, cùng với đặc điểm hình thái địa hình của vùng cửa sông ven bờ và thềm lục địa quyết định các dạng phân tỏa của vùng nước đục này. Mặc dù giá trị độ đục không đồng nghĩa với giá trị về hàm lượng trầm tích lơ lửng, tuy nhiên, việc đo đạc trực tiếp hàm lượng trầm tích lơ lửng tại các vùng cửa sông và ven biển gặp rất nhiều khó khăn, đặc biệt nếu muốn lấy mẫu trên một diện rộng. Chính vì vậy, việc sử dụng phương pháp đo độ đục bằng các thiết bị tự ghi đã được áp dụng như một phương pháp thay thế khá hiệu quả và được ứng dụng trong nhiều nghiên cứu trên thế giới $[1,2,3]$. Hơn nữa, tại khu vực cửa sông ven biển đặc biệt trong mùa lũ như của sông Cửu Long lượng trầm tích lơ lửng có thể xem là yếu tố chủ yếu làm thay đổi độ đục của môi trường nước.

Đặc điểm phân bố trầm tích lơ lửng vùng cửa 
sông ven bờ đồng bằng sông Cửu Long khá phức tạp do sự ảnh hưởng của cả chế độ động lực sông biển hỗn hợp cùng với đặc điểm địa hình. Chế độ phân bố trầm tích lơ lửng tại khu vực này đóng vai trò rất quan trọng trong quá trình hình thành và phát triển của đồng bằng châu thổ. Sông Cửu Long là con sông lớn nhất khu vực Đông Nam Á, trước khi chảy qua Việt Nam và đổ ra biển, nó chảy qua 5 nước gồm Trung Quốc, Myanmar, Thái Lan, Lào, và Campuchia. Sông Cửu Long hiện nay đổ ra biển qua 7 cửa chính: Cưa Tiểu, Cưa Đại, Cưa Ba Lai, Cưa Hàm Luông, cưa Cổ Chiên, cưa Cung Hầu, cửa Đinh An, cưa Tranh Đề (còn gọi là Trần Đề). Theo dự án "Tác động của biến đổi khí hậu lên tài nguyên nước và các biện pháp thích ứng - Đồng bằng sông Cửu Long" do Viện Khí tượng Thủy văn Hải văn và Môi trường thực hiện năm 2010, hàng năm tổng lượng nước ngọt đưa qua các cửa sông ra biển đạt tới $500 \mathrm{~km} 3$, trong đó khoảng $23 \mathrm{~km}^{3}$ được hình thành trong đồng bằng sông Cửu Long. Mùa lũ hàng năm thường kéo dài từ tháng 7 đến tháng 11 , lưu lượng dòng chảy mùa lũ chiếm khoảng 70 - 85\% lượng dòng chảy năm. Mùa cạn từ tháng 12 đến tháng 6 năm sau, lưu lượng dòng chảy mùa cạn chỉ chiếm khoảng 15 - 30\% dòng chảy năm. Lưu lượng dòng chảy tại vùng cửa sông còn chịu ảnh hưởng mạnh bởi chế độ thuỷ triều Biển Đông (bán nhật triều không đều) và vịnh Thái Lan (nhật triều không đều). Cùng với một lượng lớn nước ngọt đổ ra biển là một khối lượng trầm tích khổng lồ. Milliman và Syvitski [4] ước tính hàng năm sông Mê Kông vận chuyển khoảng 160 triệu tấn trầm tích, trong khi đó theo tính toán của Wang và nnk [5] thì con số này khoảng 145 triệu tấn trong giai đoạn từ năm 1962 - 2003. Trong đó, trung bình mỗi năm có khoảng 79 triệu tấn trầm tích chảy về đồng bằng sông Cửu Long của Việt Nam, 9 đến 13 triệu tấn lắng đọng ở các đồng bằng ngập lũ và phần còn lại góp phần mở rộng châu thổ và làm phì nhiêu các vùng nuôi trồng thủy sản ven biển [6].

Để làm sáng tỏ đặc điểm và cơ chế phân tỏa lượng trầm tích này trên vùng biển ven bờ và vùng thềm lục địa của đồng bằng sông Cửu Long đã có nhiều những nghiên cứu được thực hiện. Dựa trên việc phân tích trầm tích tầng mặt và sử dụng mô hình mô phỏng động lực, Nguyễn Trung Thành và nnk [7] đã kết luận quá trình vận chuyển trầm tích tại vùng biển ven bờ và vùng thềm lục địa của đồng bằng sông Cửu Long chịu ảnh hưởng lớn bởi chế độ dòng chảy ven bờ do sự chi phối của gió, thủy triều và các hoạt động của sóng trong vùng sát bờ biển. Trầm tích lơ lửng chủ yếu được vận chuyển về phía Tây Nam, khi vượt qua Mũi Cà Mau dòng chảy ven bờ vận chuyển trầm tích theo hướng Tây Bắc, Bắc dọc theo bờ tây bán đảo Cà Mau. Zuo Xue và nnk [8] đã sử dụng một mô hình tích hợp tính toán vận chuyển trầm tích, dòng chảy và sóng trên vùng biển ven bờ và vùng thềm lục địa của đồng bằng sông Cửu Long. Các kết quả mô hình cho thấy quá trình vận chuyển trầm tích có biến động mùa rõ rệt. Trong mùa lũ, một lượng lớn trầm tích có nguồn gốc từ sông được phân tỏa và lắng đọng ngay tại vùng cửa sông, đến mùa kiệt, hoạt động mạnh của sóng và dòng chảy do gió mùa Đông Bắc làm tái lơ lửng các trầm tích này và một phần của chúng được vận chuyển theo hướng Tây Nam dọc theo đường bờ. Để làm rõ hơn cơ chế và đặc điểm động lực trầm tích tại vùng cửa sông ven bờ đồng bằng sông Cửu Long, Hartmut Hein và nnk [9] đã đưa ra một khái niệm mới về sự phát triển của châu thổ bằng việc tích hợp thêm các thành phần dòng chảy dọc bờ trong vùng ảnh hưởng của nước do sông đổ ra (Region of Freshwater Influence - ROFI) dựa trên mô hình lý thuyết của Wollanski và nnk $[10,11]$. Các công bố của họ cũng đã chỉ ra rằng, lượng trầm tích mịn được vận chuyển xuống phía Nam đi vào vịnh Thái Lan là kết quả của sự bất đối xứng theo mùa của hệ thống gió mùa và lưu lượng nước sông. Phân tích các số liệu ảnh vệ tinh (MERIS) từ tháng 1 năm 2003 đến tháng 4 năm 2012, Hubert Loisel và nnk [12] đã xác định được phân bố không gian của trầm tích lơ lửng tại lớp nước mặt theo mùa. Độ đục tăng dần từ tháng 6 đến tháng 12 cùng với nguồn trầm tích từ sông đổ ra tăng dần, đạt cực đại vào tháng 9 và 
tháng 10. Khi lưu lượng nước sông giảm, nồng độ trầm tích lơ lửng vẫn tiếp tục tăng tại vùng biển ven bờ trong 2 đến 3 tháng (tháng 11 đến tháng 1 năm sau). Điều này được lý giải là do hoạt động mạnh của sóng trong gió mùa Đông Bắc làm tăng quá trình tái lơ lửng trầm tích tại vùng biển ven bờ. Các kết quả nghiên cứu cũng cho thấy xu hướng vận chuyển trầm tích lơ lửng về phía Tây Nam trong mùa gió Đông Bắc.

Tuy nhiên, có thể thấy hầu hết các kết quả nghiên cứu về biến động trầm tích lơ lửng tại khu vực nghiên cứu dựa trên các mô hình tính toán, ngay cả các kết quả phân tích ảnh vệ tinh cũng chỉ thể hiện được biến động theo phương ngang của lớp nước mặt. Do đó, để đóng góp những hiểu biết rõ hơn đặc điểm biến động trầm tích lơ lửng tại khu vực này trong mùa lũ, số liệu độ đục và độ muối tại các trạm đo mặt rộng khu vực cửa sông Cửu Long do đề tài: "Nghiên cứu động lực thủy văn, xâm nhập mặn và vận chuyển trầm tích của hệ thống sông Cửu Long và động lực ven bờ, bao gồm cả bán đảo Cà Mau" thực hiện trong tháng
9/2013 đã được xử lý, phân tích và đánh giá.

\section{Nguồn số liệu}

Đặc điểm biến động theo không gian và thời gian của trầm tích lơ lửng trong mùa lũ năm 2013 tại vùng cửa sông ven bờ đồng bằng sông Cửu Long được đánh giá dựa trên việc phân tích số liệu độ đục và độ muối của 65 trạm đo mặt rộng trong tháng 9/2013 (hình 1). Số liệu độ đục và độ muối từ mặt đến đáy tại từng trạm được đo bằng thiết bị đo chất lượng nước đa chỉ tiêu AAQ1183s-IF do Nhật Bản sản xuất với tần xuất đo là $0,2 \mathrm{~s}$ có một số liệu để đảm bảo độ phân giải số liệu theo phương thắng đứng đủ chi tiết (tốc độ thả kéo là khoảng $0,5 \mathrm{~m} / \mathrm{s}$ ). Sau đó các số liệu được nội suy về độ phân giải thẳng đứng là 0,1 $\mathrm{m}$ để có thể dễ dàng tính toán và vẽ các biểu đồ. Ảnh hưởng của triều đối với các đặc trưng phân bố trầm tích lở lửng được phân tích dựa trên số liệu triều dự báo của Viện Kỹ thuật Biển cho hai trạm Bến Trại và Mỹ Thanh (hình 1) tại khu vực nghiên cứu [13].

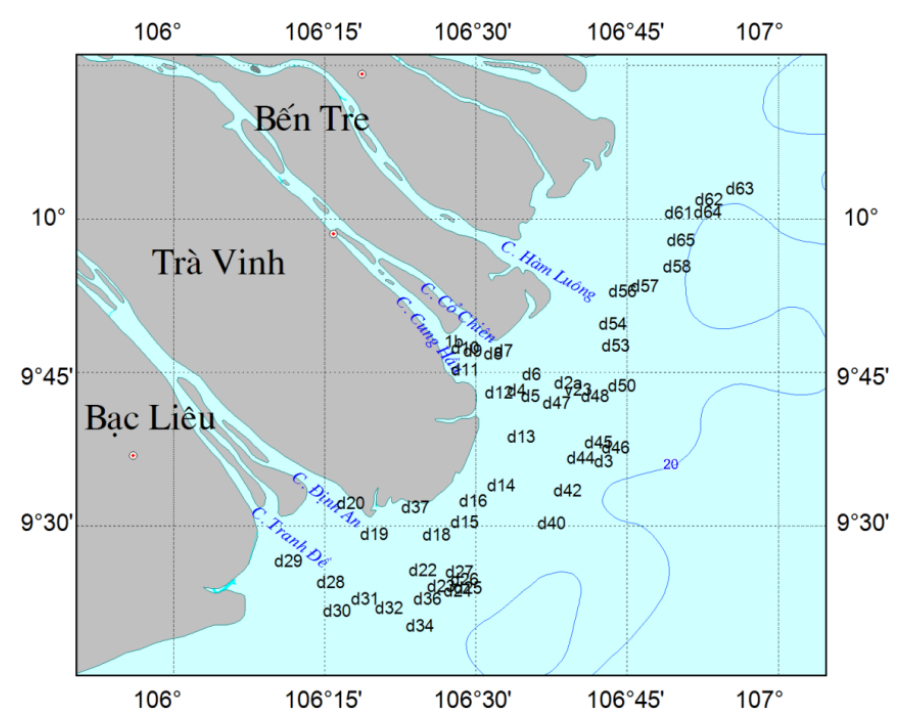

Hình 1. So đồ vị trí trạm triều dụ báo, các trạm khảo sát mặt rộng và mặt cắt (A1, A2) tháng 9/2013

\section{3. Đặc trưng biến động của trầm tích lơ lửng tại vùng cửa sông Cửu Long mùa lũ năm 2013}

Phân bố theo không gian của độ đục và độ muối tại tầng mặt (trung bình trong lớp $1 \mathrm{~m}$ trên mặt) cùng vị trí các trạm khảo sát được thể hiện trong hình $2 \mathrm{a}$ và $2 \mathrm{~b}$. Nhìn chung, phân bố theo không gian của độ đục ngược lại với phân bố của độ muối. Độ đục có xu thế giảm dần từ vùng cửa sông ra vùng ngoài khơi do ảnh hưởng của nguồn trầm tích từ sông đổ ra lớn trong mùa lũ. Tuy nhiên vùng có phân bố độ đục cao chủ yếu tập trung tại khu vực thẳng từ cửa sông ra ngoài khơi. Tại vùng cửa sông độ đục có thể lên tới gần 
800 NTU tại trạm D30 (cửa Tranh Đề), hơn 130 NTU tại trạm D1 (cửa Cổ Chiêm). Có thể thấy, giá trị độ đục tại các trạm khu vực cửa Tranh Đề và Định $\mathrm{An}$ cao hơn rất nhiều so với các cửa sông khác, ngay cả tại trạm xa bờ nhất như trạm

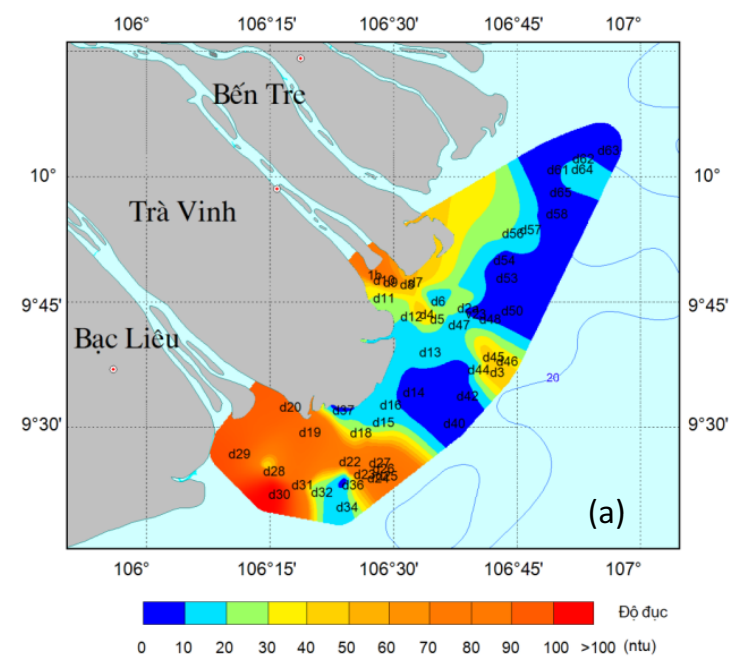

D25 độ đục tại tầng mặt cũng lên đến 130 NTU. Khu vực biển ven bờ Trà Vinh ít chịu ảnh hưởng trực tiếp của cửa sông nên có độ đục nhỏ chỉ khoảng 10 đến $20 \mathrm{NTU}$ và độ muối lớn từ 25 PSU đến hơn 30 PSU (Practical Salinity Unit).

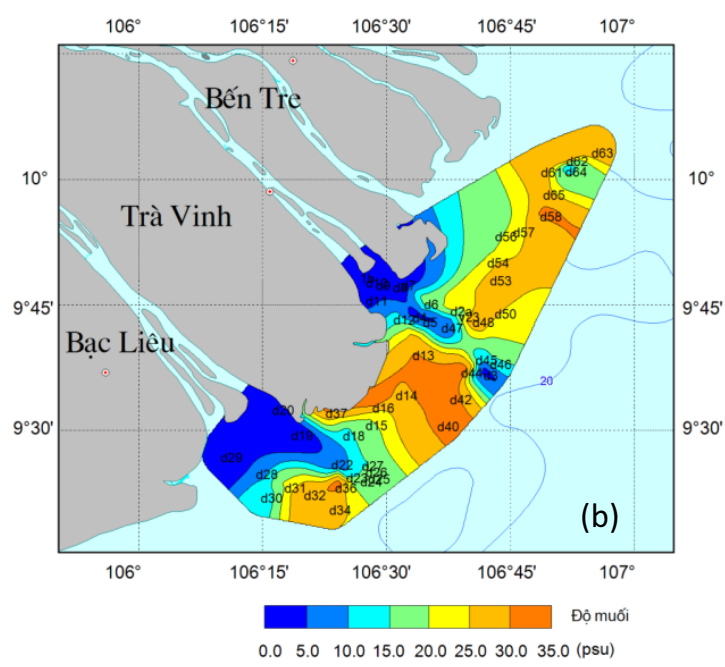

Hình 2. Phân bố theo không gian của (a) độ đục và (b) độ muối tại tầng mặt cùng vị trí các trạm khảo sát

Phân bố thẳng đứng của độ đục theo không gian biến đổi mạnh phụ thuộc vào vị trí quan trắc và thời điểm quan trắc theo pha triều. Hình 3 và 5 thể hiện phân bố thẳng đứng của độ đục và độ muối trên mặt cắt $\mathrm{A} 1$ và $\mathrm{A} 2$. Do các trạm trên hai mặt cắt $\mathrm{A} 1$ và $\mathrm{A} 2$ được đo vào các thời điểm khác nhau với đặc điểm pha triều khác nhau nên phân bố không gian của độ đục và độ muối thể hiện rất rõ vai trò tác động của dòng triều theo pha triều (xem thêm hình 4 và 6). Trên mặt cắt A1 tại khu vực cửa Tranh Đề (hình 3), trạm D29 và $\mathrm{D} 30$ được đo đạc trong pha triều rút với biên độ triều trong ngày lớn khoảng hơn 2,7 m, dòng

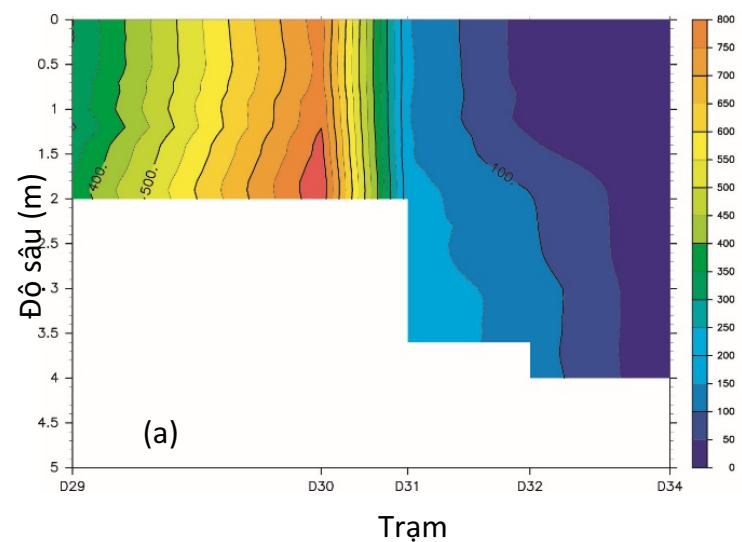

triều kết hợp với dòng chảy ra do sông đã phân tỏa trầm tích và nước ngọt ra vùng cửa sông. Phân bố độ đục tại hai trạm này có xu thế tăng dần từ mặt đến đáy, độ đục cực đại đạt tới hơn 800 NTU tại trạm D30, độ muối khá đồng nhất từ mặt đến đáy (hình 3 và 4 ). Trong khi đó các trạm D31, D32 và D34 được thực hiện trong pha triều lên, lúc này mực nước biển cao lan truyền ngược vào vùng cửa sông ngăn cản sự phân tỏa của trầm tích và nước ngọt, độ đục tại các trạm này suy giảm nhanh chóng tuy vẫn thể hiện xu thế tăng dần từ mặt đến đáy, độ đục tại trạm D34 xa bờ nhất chỉ con khoảng 15 NTU.

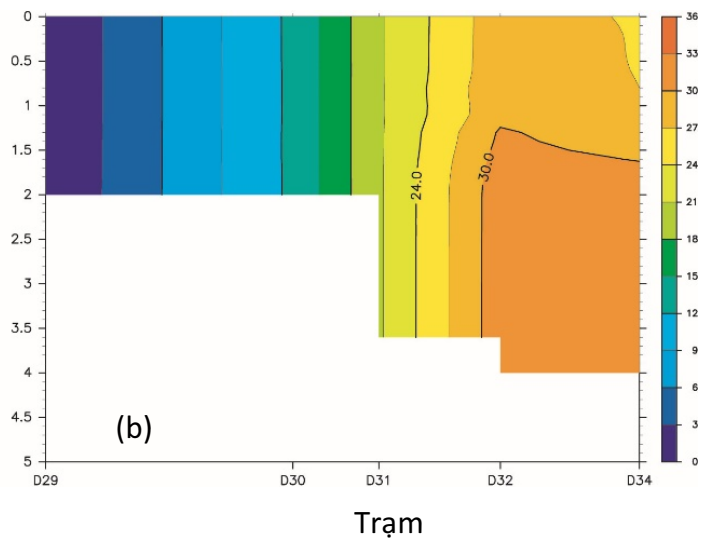

Hình 3. Mặt cắt phân bố thẳng đứng của (a) độ đục (NTU) và (b) độ muối (PSU) tù cưa sông ra khoi (Mặt cắt A1 tù̀ trạm D29, D30, D31, D32 và D34) ngày 21/09/2013 tại cửa Tranh Đề 


\section{BÀI BÁO KHOA HỌC}

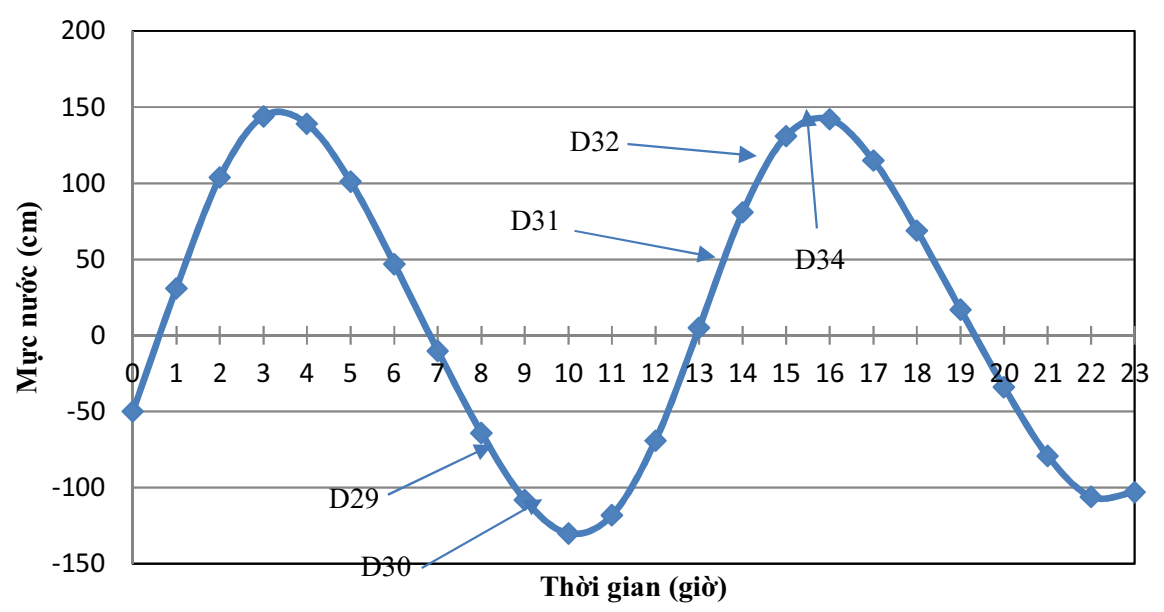

Hình 4. Dao động triều dụ báo tại Mỹ Thanh (gần cưa Tranh Đề) vào ngày 21/09/2013 và thò̀i điểm đo của các trạm tuoong úng trên mặt cắt Al

Trên mặt cắt A2 tại khu vực cửa Cổ Chiên (hình 5), phân bố thẳng đứng của độ đục lại có xu thế giảm dần từ mặt đến đáy, tại lớp mặt độ đục tại trạm D3 xa bờ nhất vẫn lên đến hơn 40 NTU. Thêm vào đó, độ muối thể hiện sự phân tầng rõ rệt mặc dù hầu hết các trạm được quan trắc trong pha triều lên ngoại trừ trạm $\mathrm{D} 10$ quan

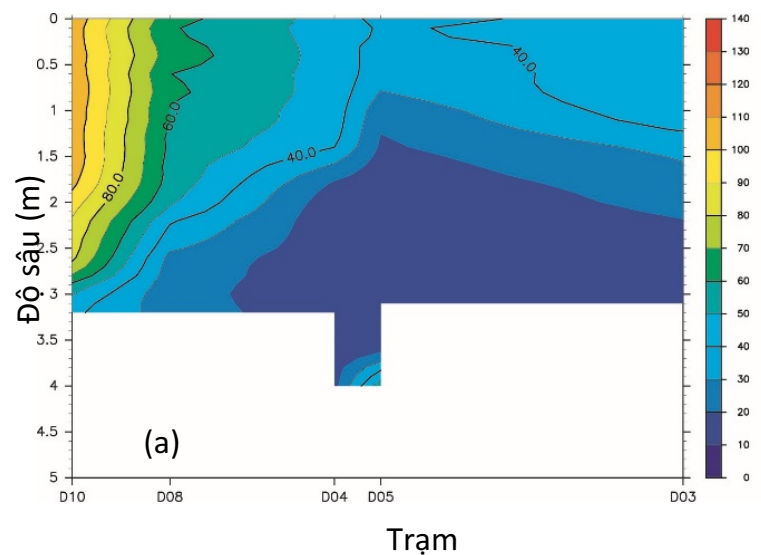

trắc trong pha triều xuống. Điều này có thể do biên độ triều lên tại thời điểm quan trắc nhỏ chỉ khoảng 1,25 m. Các giá trị độ muối nhỏ và độ đục vẫn còn cao tại tầng mặt ở trạm D3 cho thấy ảnh hưởng của triều trong pha triều lên này là không lớn.

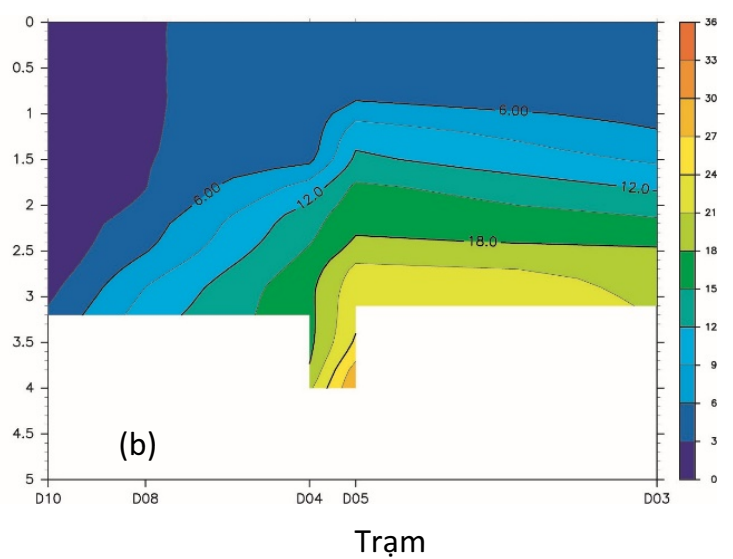

Hình 5. Mặt cắt phân bố thẳng đứng của (a) độ đục (NTU) và (b) độ muối (PSU) tù cưa sông ra khơ (Mặt cắt A2 tù̀ trạm D10, D8, D4, D5 và D3) ngày 17/09/2013 tại cửa Cổ Chiên

Hình 7 và hình 8 thể hiện biến động theo pha triều của phân bố thẳng đứng độ đục và độ muối tại trạm D2 phía ngoài cửa Cổ Chiên. Trong pha triều rút, dòng triều kết hợp với dòng chảy sông đưa nước ngọt có độ đục cao ra xa phía ngoài cửa sông, phân bố thẳng đứng của độ đục và độ muối tại trạm D2 khá đồng nhất. Khi mực triều đạt giá trị cực tiểu, tốc độ dòng triều tại thời điểm này nhỏ làm cho quá trình lắng đọng trầm tích tăng mạnh. Độ đục tại tầng mặt giảm nhanh chóng trong khi độ đục tại tầng đáy tăng (thời điểm 18 giờ 10 phút). Khi bắt đầu pha triều lên, ảnh hưởng của nước sông giảm đáng kể làm cho độ đục từ mặt đến đáy đều giảm cùng với đó là sự tăng mạnh của độ muối. 


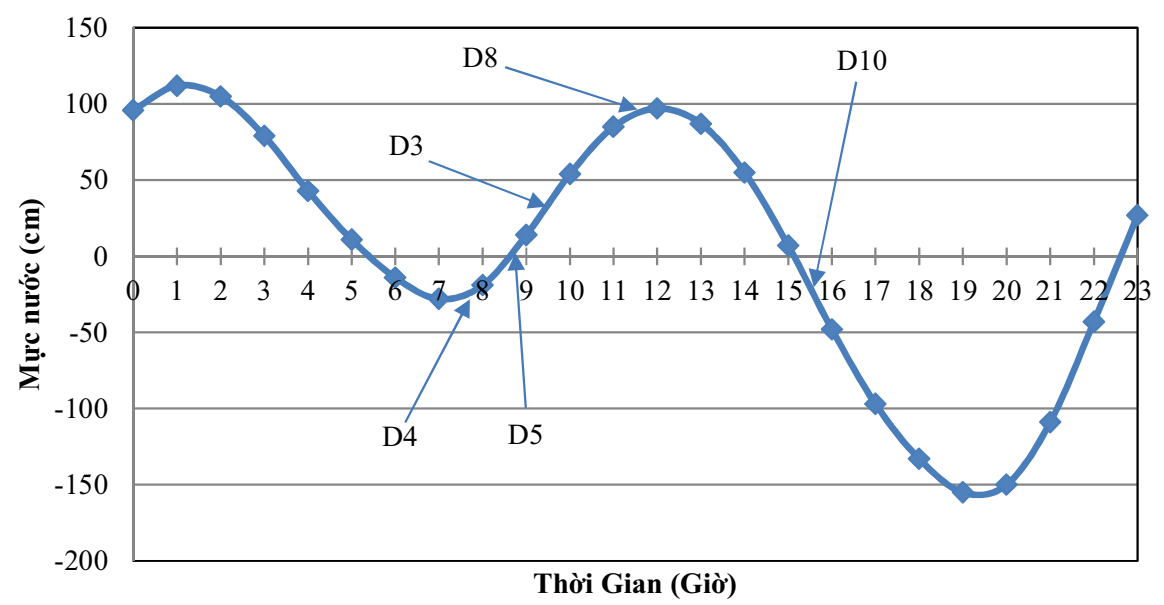

Hình 6. Dao động triều dụ báo tại Bến Trại (gần cưa Cổ Chiên) vào ngày 17/09/2013 và thòi điểm đo của các trạm tưong ứng trên mặt cắt A2
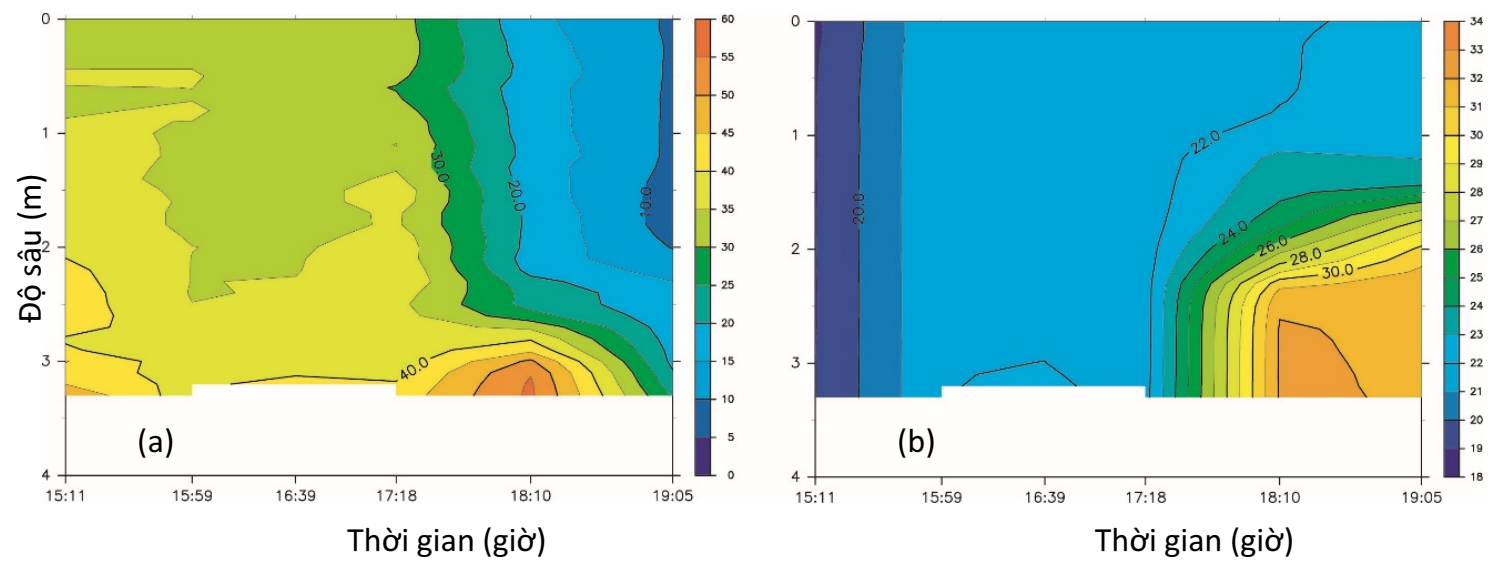

Hình 7. Phân bố thẳng đứng của (a) độ đục (NTU) và (b) độ muối (PSU) theo thời gian tại trạm D2 ngày 16/09/2013 tại cứa Cổ Chiên

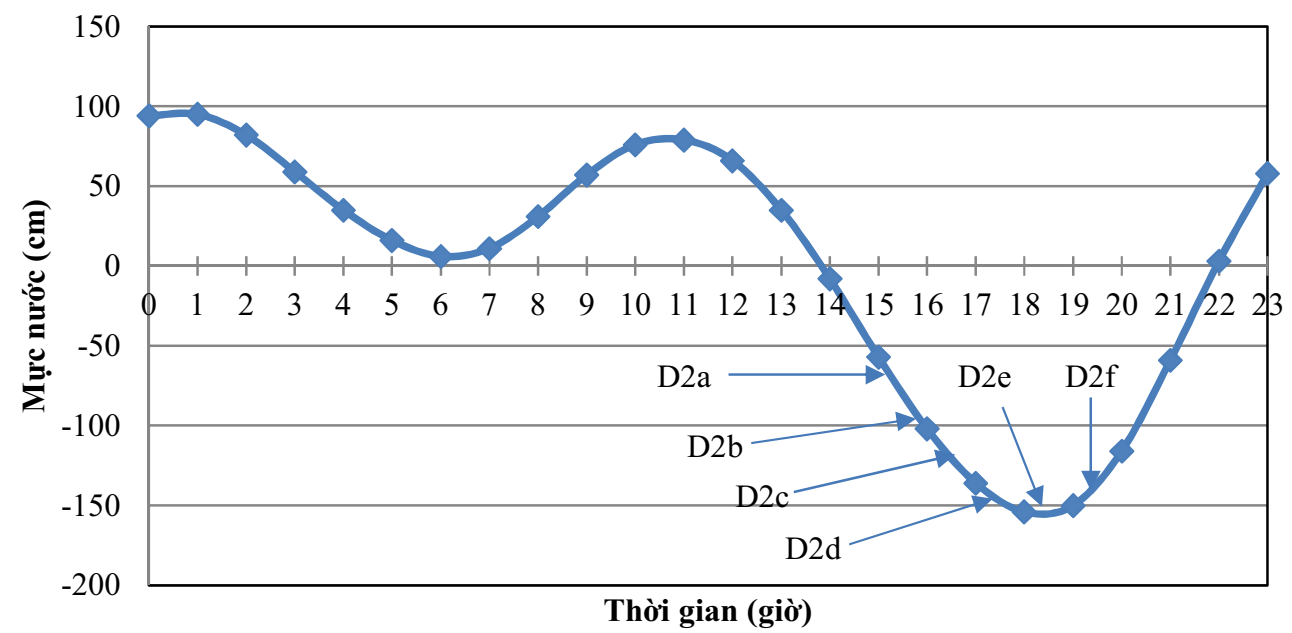

Hình 8. Dao động triều dụ báo tại Bến Trại (gần của Cổ Chiên) vào ngày 16/09/2013 và các thời điểm đo khác nhau tại trạm D2 


\section{BÀI BÁO KHOA HỌC}

Một điểm đặc biệt cũng cần được nhắc tới là hầu hết các trạm quan trắc đều thể hiện phân bố thẳng đứng của độ đục và độ muối phù hợp với vị trí và thời điểm đo theo pha triều, tuy nhiên có một số trạm quan trắc được sự phân bố thẳng đứng của độ đục và độ muối khác biệt (ví dụ trạm 31 và 48). Cả hai trạm đều được đo vào thời điểm trong pha triều lên với biên độ triều lớn hơn $2 \mathrm{~m}$, vị trí đều nằm xa khu vực cửa sông (hình 1 và hình 4). Giá trị độ muối cao suốt từ mặt đến đáy dao động quanh 30 psu và giá trị độ đục tầng

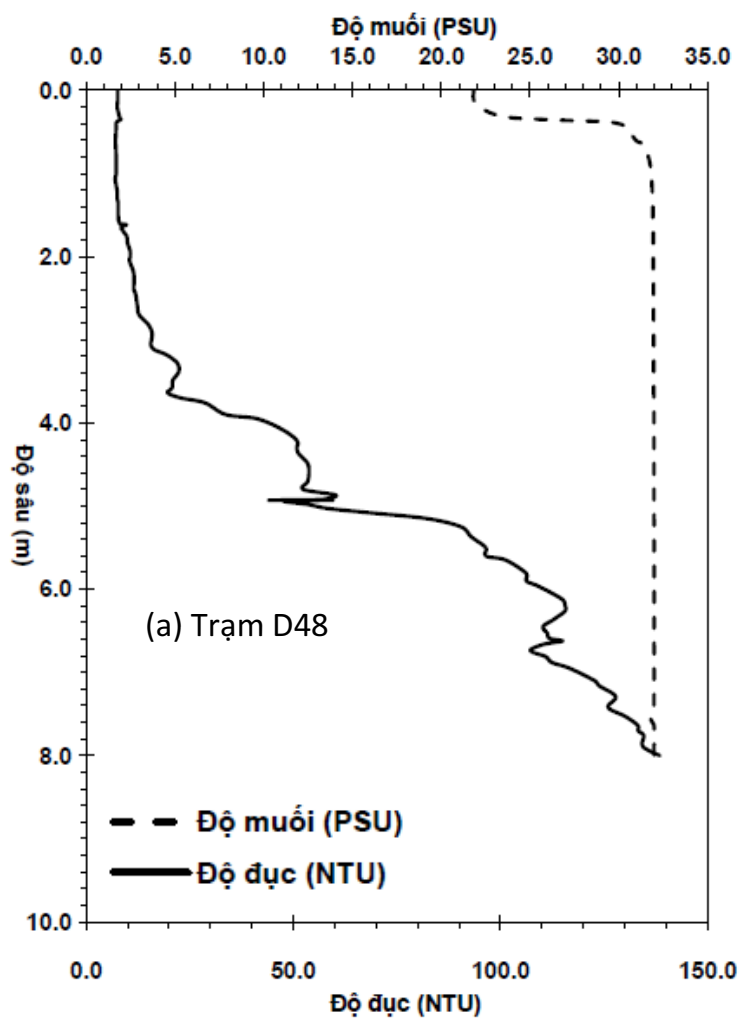

Hình 9. Phân bố thăng đứng độ đục và độ muối tại (a) trạm D48 và (b) trạm D32

Như vậy có thể thấy chế độ thủy văn sông và triều đóng vai trò lớn đối với phân bố trầm tích lơ lửng theo không gian và thời gian tại vùng cửa sông Cửu Long trong mùa lũ tháng 9/2013. Bằng việc phân tích từ các số liệu khảo sát thực địa, các kết quả này cũng đã củng cố thêm những nhận định về đặc điểm phân bố theo không gian của trầm tích lơ lửng tầng mặt trong mùa lũ của Zuo Xue và nnk [8], Hartmut Hein và nnk [9] và Hubert Loisel và nnk [12].

\section{Kết luận}

Trong nghiên cứu này, đặc điểm biến động mặt nhỏ (chỉ khoảng 2 ntu tại trạm D48 và 6 NTU tại tram D32) cho thấy các trạm này gần như không còn chịu ảnh hưởng của khối nước ngọt với độ đục cao từ sông đổ ra (hình 9). Tuy nhiên, tại tầng đáy độ đục tăng đột biến lên tới 140 NTU. Hiện tượng này có thể liên quan tới quá trình tái lơ lửng của trầm tích do dòng triều như đã được đề cập trong nghiên cứu của Daniel Unverricht và nnk [14]. Các phân tích chi tiết về hiện tượng này sẽ được thực hiện trong những nghiên cứu tiếp theo.

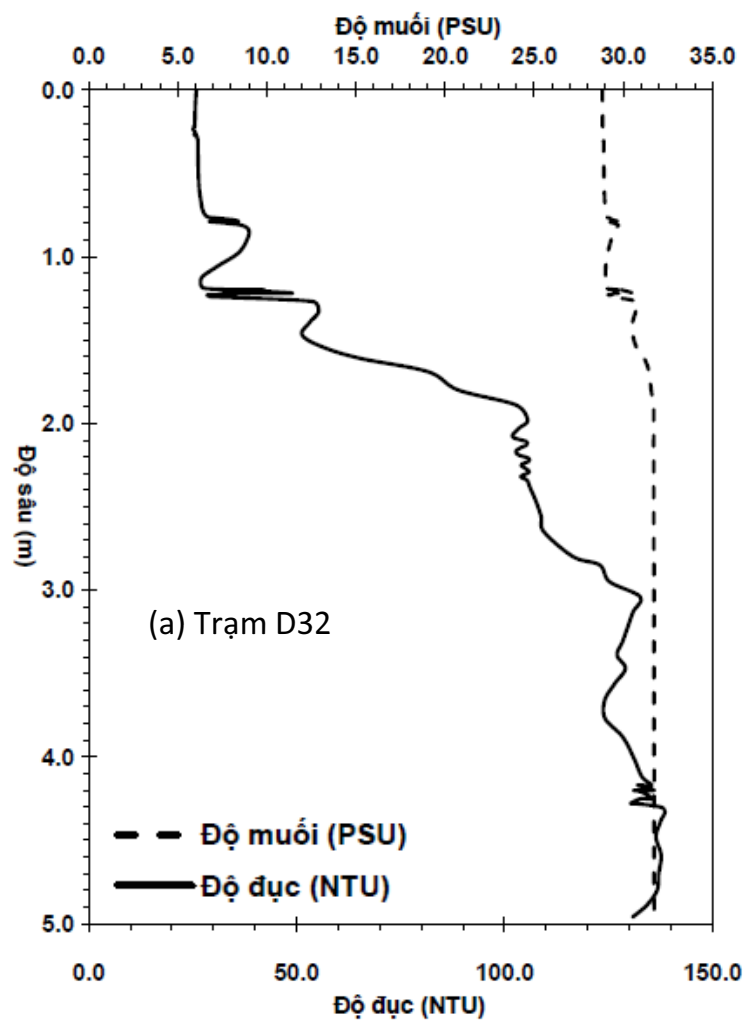

trầm tích lơ lửng trong mùa lũ tháng 9/2013 đã được phân tích và đánh giá bằng việc sử dụng các số liệu khảo sát thực địa về độ đục và độ muối kết hợp với đặc điểm của chế độ triều. Các kết quả phân tích số liệu cho thấy phân bố không gian và thời gian của độ đục tại vùng cửa sông Cửu Long trong mùa lũ tháng 9/2013 chịu ảnh hưởng mạnh của hai chế độ động lực chính: chế độ thủy văn tại các cửa sông và chế độ triều. Theo không gian, phân bố độ đục có xu hướng giảm dần từ vùng cửa sông ra vùng ngoài khơi do ảnh hưởng của nguồn trầm tích từ sông đổ ra 
cùng với hoạt động mạnh của thủy triều. Tại vùng cửa sông độ đục có thể lên tới hơn 800 NTU. Phân bố thẳng đứng của độ đục biến đổi phụ thuộc vào vị trí quan trắc và thời điểm quan trắc theo pha triều. Ở một số trạm quan trắc được sự tăng đột biến của độ đục tại lớp sát đáy có thể liên quan tới quá trình tái lơ lửng của trầm tích do dòng triều trong pha triều lên. Các trạm tại khu vực cửa sông Hậu có độ đục cao hơn so với các trạm tại khu vực cửa sông Tiền.

Lời cảm ơn: Công trình nghiên cứu này đã được cung cấp số liệu khảo sát tì̀ Nhiệm vu Nghị định thư giữa Việt Nam và Hoa Kỳ (2013-2015). Cảm on thạc sĩ Vũ Hải Đăng đã cung cấp số liệu để hoàn thiện bài báo.

\section{Tài liệu tham khảo}

1. Gippel, C.J., (1995), Potential of turbidity monitoring for measuring the transport of suspended solids in streams. Hydrol. Process. 9, 83-97.

2. Chanson, H., Takeuchi, M., Trevethan, M., (2008), Using turbidity and acoustic backscatter intensity as surrogate measures of suspended sediment concentration in a small subtropical estuary. J. Environ. Mana. 88, 1406-1416.

3. Meral, R., (2016), A study on the estimating of sediment concentration with turbidity and acoustic backscatter signal for different sediment sizes. Hydro. Res. 305-311.

4. Milliman, J.D., Syvitski, J.P.M., (1992), Geomorphic/tectonic control of sediment discharge to the ocean: the importance of small mountainous rivers. J. Geol. 100, 525-544.

5. Wang, J.J., Lu, X.X., Kummu, M., (2011), Sediment load estimates and variations in the Lower Mekong River. River Res. Appl. 27, 33-46. http://dx.doi.org/10.1002/rra.1337.

6. Pukinskis, I., (2013), Mekong Sediment Basics, State of Knowledge Series 2, Vientiane, Lao $P D R$, Challenge Program on Water and Food.

7. Nguyễn Trung Thành, Nguyễn Hồng Lân, Phùng Văn Phách, Dư Văn Toán, Bùi Việt Dũng, Daniel Unverricht, Karl Statteger, (2011), Xu hướng vận chuyển tích tụ trầm tích trên phần châu thổ ngầm ven bờ biển đồng bằng sông Mê Kông. Tạp chí Các Khoa học về trái đất, 33 (4), 607-615.

8. Xue, Z., He, R., Liu, J.P., Warner, J.C., (2012), Modeling transport and deposition of the Mekong River sediment. Continental Shelf Research, 37, 66-78.

9. Hein, H., Hein, B., Pohlmann, T., (2014), Recent sediment dynamics in the region of Mekong water influence. Global and Planetary Change, 110, 183-194.

10. Wolanski, E., Ngoc Huan, N., Trong Dao, L., Huu Nhan, N., Ngoc Thuy, N., (1996). Finesediment dynamics in the Mekong River Estuary, Vietnam. Estuarine, Coastal and Shelf Science, 43 (5), 565-582.

11. Wolanski, E., Nguyen, H.N., Spagnol, S., (1998), Sediment dynamics during low flow conditions in the Mekong River Estuary, Vietnam. J. Coastal Res. 14, 472-482.

12. Loisel, H., Mangin, A., Vantrepotte, V., Dessailly, D., Dinh, D.N., Garnesson, P., Ouillon, S., Lefebvre, J.P., Mériaux, X., Phan, T.M., (2014), Variability of suspended particulate matter concentration in coastal waters under the Mekong's influence from ocean color (MERIS) remote sensing over the last decade. Remote Sensing Envi. 150, 218-230.

13. Viện Kỹ thuật Biển, Bảng dự tính Thủy Triều năm 2013 http://www.icoe.org.vn/index.php.

14. Unverricht, D., Nguyen, T.C., Heinrich, C., Szczucin'ski, W., Lahajnar, N., Stattegger, K., (2014), Suspended sediment dynamics during the inter-monsoon season in the subaqueous Mekong Delta and adjacent shelf, southern Vietnam. J. Asian Earth Sci. 79, 509-519. 


\title{
CHARACTERISTICS OF SUSPENDED SEDIMENT VARIATION DURING THE 2013 FLOOD SEASON IN MEKONG DELTA COASTAL ESTUARINE AREA
}

\author{
Nguyen Ba Thuy', Vu Hai Dang² \\ ${ }^{1}$ National Hydrological Forecasting Center \\ ${ }^{2}$ Institute of Marine Geology and Geophysics, VAST
}

\begin{abstract}
Spacial and temporal variations in suspended sediment characteristics during the 2013 flood season in Mekong Delta coastal estuarine area have been elucidated based on analyzing turbidity and salinity data of 65 stations in September 2013. The turbidity and salinity data from the surface to the bottom are measured by AAQ1183s-IF instrument. The tidal influence to dynamic characteristics of suspended sediment is analyzed based on tidal prediction data in the study area. The results show that temporal and spatial distributions of turbidity in the Mekong estuary during flood season are affected by two major dynamics regimes: hydrological regime in estuaries and tidal regime. Spatial turbidity distribution tends to decrease gradually from the estuary to the offshore area due to the sediment source from river together with strong activity of tide. In estuaries, turbidity can be up to more than 800 NTU (Nephelometric Turbidity Units). Vertical turbidity distributions change depending on location and time of observations and tidal phases. In several stations, there are sudden increases of turbidity in layers near the bottom up to 140 NTU, although salinity values from surface to bottom are relatively high and the observation times are in flood tide phase. This phenomenon may be related to the process of resuspension of bottom sediments by tidal current in flood tide phase. In general, turbidities at Dinh An estuarine stations are higher than those at Tien branch of Mekong estuarine stations.
\end{abstract}

Keywords: Suspended sediment dynamics, turbidity, salinity, tide, Mekong Delta coastal estuarine area. 